\title{
Assessment of macroeconomic and ecological security of Vietnam in the current period
}

\author{
Huong Le Thi Mai ${ }^{1, *}$, Vang Dang Quang ${ }^{1}$, and Thinh Bui Tien ${ }^{1}$ \\ ${ }^{1}$ Ho Chi Minh University of Technology and Education, Ho Chi Minh City, Vietnam
}

\begin{abstract}
The article highlights the state of financial security in Vietnam in the period of $2000-2018$. Based on secondary data collected from agencies such as the International Monetary Fund, the World Bank, and the State Bank of Vietnam Nam and based on four groups of indicators measuring financial security, namely the wealth level of the people, namely the wealth level of the people, economic scale and level of development, Prospects of economic growth, Economic stability. The research results show that before 2007, the level of integration of the economy was still low, so the financial security indicators were supported by the national debt situation, the ratio of high bad debt, High budget deficit, ineffective financial and monetary monitoring activities have not contributed much to security, and these indicators are quite low when compared to other countries in the region.
\end{abstract}

\section{Introduction}

Vietnam's financial market is growing rapidly and vibrantly, but also poses major challenges in ensuring national and corporate financial security. In the context of deeper and deeper international economic integration, the instabilities of the world financial markets directly affect the management of exchange rates, interest rates, national debts, inflows of I / O as well as risks of Vietnamese financial institutions in the financial market. Many countries around the world have paid more attention to the design of financial security systems [1].

In particular, a number of requirements have been made including:

(1) Healthy financial institutions with inter-sectorial coordination mechanisms, create a solid legal basis for information exchange;

(2) Empowering early intervention in problem banks to prevent disruption;

(3) Give additional powers to handle and definitely deal with relevant issues;

(4) Design a good deposit guarantee plan - final shelter;

(5) There are government support programs. After more than 30 years of economic reform,

(6) There are government support programs.

After more than 30 years of economic reform, Vietnam's monetary and financial system has formed quite a full range of necessary components, including financial institutions, financial instruments and supervision models $[2,3]$.

* Corresponding author: tranhungln@gmail.com 
However, the current financial system in our country still has some limitations such as

- The financial market has not established a sufficient and effective operating mechanism;

- Monitoring the financial system in Vietnam has many limitations that exist;

- The ability to cope with market shocks and regulate external capital into the economy is low;

- Potential risks to financial system stability.

These issues threaten the financial security situation of the country from the above situation, the article assessing the situation of financial security in Vietnam in the current period aims to assess the financial security situation.

These issues threaten the financial security situation of the country from the above situation, the article assessing the situation of financial security in Vietnam in the current period aims to assess the financial security situation. It is precisely in Vietnam in the context of the current international integration that specifically analyzes the situation of macro-financial security based on specific evaluation criteria. This helps relevant agencies have a correct view of the financial security situation in Vietnam in the current period and responding to contribute to ensuring national financial security in general and economic development in particular.

\section{Theoretical basis}

\subsection{The concept of financial security}

[4]: financial security is a component of economic security and covers the financial relationships of economic entities (household, company, state, region, and region) and reflect absence of real threats (ability to combat potential threats) in the distribution and redistribution of gross domestic product to different levels: micro, intermediaries and macro.

[5] argues that financial security does not only consist in financial stability because this concept does not cover the government's public financial status. The author concludes that when considering the financial security of a country, it is necessary to consider financial stability, monetary stability and the sustainability of public finance.

[6] set that financial security is a basic concept to indicate a stable, safe and strong financial situation.

Thus, financial security is understood as a generally stable, safe economic situation, be strong and not in crisis

\subsection{Evaluation criteria}

The indicators are used to assess financial security at the Macro level is divided into 2 aspects, 4 main factors and 19 indicators [7, 8]. Specifically:

Two key aspects include: (1) the operational strength of the economy and the policy environment and (2) the assessment of the financial sector.

(1) Economic strength and policy environment: assessment of national economic power and activity, international balance of payments and external influences, government administrative capacity, and fiscal policies and monetary policy.

(2) Financial sector assessment: assessment of financial performance, level of financial development, financial control and financial stability.

The four main factors include:

(1) Strength and economic activity include: people's wealth level (real GDP per capita), economic scale and development level (real GDP and economic growth), development 
economic growth expectation (real GDP per capita growth), economic stability (fluctuations of per capita GDP and unemployment rate)

(2) Administrative capacity and policy effectiveness include: effectiveness of fiscal policy (government debt / GDP change ratio), government debt (government debt burden / GDP), financial costs (government debt costs), debt serviceability (debt obligations / export turnover), default risk (public debt / GDP ratio), dependence on foreign countries (billion foreign debt / GDP ratio, fiscal revenues and expenditures (budget deficit / GDP), inflation and monetary value stabilization (CPI).

(3) The balance of international payments and external influences include: the level of export orientation (the degree of dependence on foreign trade, the trade balance / GDP), the level of international payments (current balance / GDP), capital account (inflows / outflows / GDP), liquidity and reasonableness of foreign exchange reserves (total foreign reserves)

(4) Financial development activities include: level of financial development (credit growth or level of stock market development), financial asset price (real interest rate), and exchange rate fluctuation exchange.

On the basis of the indicators evaluating the macroeconomic security situation of an IMF country, summarizing domestic and foreign studies and on the basis of being able to access data in Vietnam on indicators Financial security criteria, the thesis assesses the situation of macro-financial security in Vietnam based on the four main factors that have been classified above. At the same time, based on qualitative and quantitative criteria to make judgments about the level of financial security in Vietnam from 2000 to 2018.

\section{Data and research methods}

Secondary data related to the financial security situation at the macro level; The system of documents related to financial security activities was collected from agencies such as IMF, WB, ASEAN Stats, General Statistics Office, General Department of Customs ... and specialized scientific journals. On that basis, conducting statistics, comparing, analyzing, synthesizing and evaluating research content.

The paper uses data analysis methods, descriptive statistical methods and comparative methods; The statistical method describes and evaluates the financial security situation of Vietnam on the main factors of strength and economic activity;

Administrative capacity and policy effectiveness; International balance of payments and external influences; Operation and development of financial markets; The general analysis method is used in the whole process of project implementation.

Summarize all collected data, conduct an analysis and assessment of Vietnam's financial security situation based on evaluation criteria; Comparative method: comparing and evaluating Vietnam's financial security indicators compared to other countries in the region.

\section{The reality of macroeconomic security in Vietnam through indicators}

\subsection{Power and economic activity}

This indicator is measured by the following factors:

(1) People's wealth level:

To measure the wealth of people often use the GDP Index (Gross Domestic Product). According to [8] and many other authors, when evaluating "economic power and activity", GDP per capita is used as a measure of people's wealth. On that basis, based on published 
data of the World Bank (World Bank) to compare and assess the wealth of Vietnam with a number of countries in the region and in the world.

According to data published by the World Bank (World Bank), the real GDP per capita of Vietnam has increased rapidly since 2000. Specifically, in 2000, the average real GDP of Vietnamese people reached 390.1 USD / person / year, by 2010 it reached 1317.9 USD, an increase of 3.37 times compared to 2010.

In 2018, the real average GDP per capita Vietnam's people reached US \$ 2,566.6, an increase of 6.5 times compared to 2000 and an increase of 1.9 times compared to 2010, an increase of 1.08 times compared to 2017. Average GDP per capita of Vietnam in the period in the 2000-2018 period, it will reach 1,824.6 USD / person / year, GDP per capita in the 2010-2018 period will reach 1967.1 USD / person / year.

However, compared to other ASEAN countries such as Thailand, Indonesia and Malaysia, Vietnam's real GDP per capita is quite low.

Specifically, according to World bank statistics, Singapore's real GDP per capita in 2018 was 25.8 times that of Vietnam, Brunei 12.6 times, Malaysia 4.5 times and Thailand having real GDP. per capita nearly 2.8 times Vietnam,Indonesia 1.5 times. Vietnam's real GDP per capita is only higher than that of Laos and Myanmar. Compared with the criteria "The richness of the people" of Cheng (2015), in the period of 2000-2018 Vietnam reached the second level, which is a low level of financial security. Thus, considering the criteria of the wealth of the people, Vietnam reached a low level and from that the level of financial security is also low.

(2) Economic scale and level of development

Economic size is measured through real GDP. Vietnam's real GDP has continuously increased over the years since 2000. In 2000, Vietnam's real GDP reached 31.17 billion USD, by 2010 Vietnam's real GDP reached 115.93 billion USD. In 2018, Vietnam's real GDP reached 245.21 billion USD, an increase of 2.11 times compared to 2010 and an increase of 7.86 times compared to 2000 .

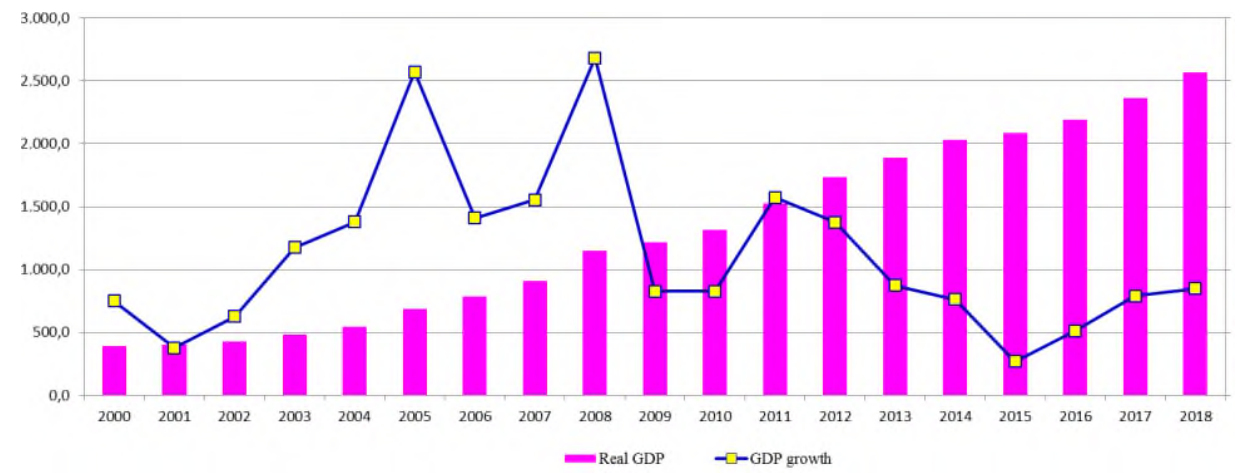

Fig. 1. Vietnam's real GDP and GDP growth period 2000 - 2018. Source: World Bank.

(3) Prospects of economic growth.

Prospects of economic growth are used to assess the status of financial strength at the current stage and the ability to ensure financial security in the future. Based on Cheng (2015), this indicator is concretized through the target GDP per capita growth rate. The real GDP per capita growth in Vietnam continued to grow continuously during the period 2000 - 2018 and reached an average of $11.3 \%$ per year, as shown in the following graph: 


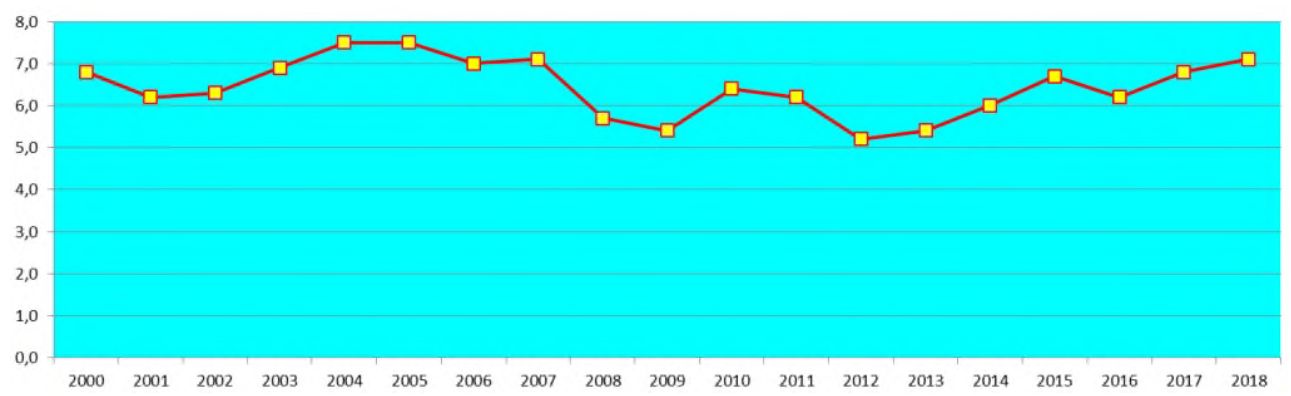

Fig. 2. Vietnam's annual real GDP per capita growth period. 2000 - 2018 (Unit: \%) (Source: Calculated from World Bank data).

Despite achieving continuous growth over the years, the rea 1 GDP growth rate per capita in Vietnam has fluctuated over the years.

This shows that people's living standards are gradually improving and increasing, people's wealth is on the rise, which is a positive sign to enhance national economic and financial security, thereby The country has more resources to deal with instability.

(4) Economic stability

This indicator is measured through fluctuations in GDP per capita and unemployment rate. From 2000 to 2007, the economy was quite stable, so the real GDP per capita fluctuation in Vietnam was negligible. Since 2007, Vietnam has become more and more integrated through WTO accession and many bilateral and multilateral trade agreements, making the economy vulnerable to market fluctuations. in the international market, it partly makes the economy unstable and unstable, the efficiency and sustainability is not high.

Unemployment rate: ASEAN economies have recovered strongly in recent years. Unemployment in the ASEAN bloc fell slightly to $3.7 \%$ in 2018 , lower than the world average of $6.2 \%$.However, the unemployment rate among young people is very high $(13.5 \%)$. In the ASEAN region, Vietnam is a country with low unemployment, Vietnam ranks 8 th among the countries with the lowest unemployment rate $(2 \%)$, which is ranked in the top $5 \%$ of countries and regions. territory.

\subsection{Administrative capacity indicators and policy efficiency}

(1) Debt situation of the National and the Government

Based on the above-mentioned indices of debt level, comparing with Vietnam, we find that Vietnam's foreign debt level is at level 2 (difficult debt level).

In the 2000-2010 period, Vietnam's average foreign debt level / GDP reached 35.94\%, from 2010 onwards Vietnam's foreign debt level tended to increase and reached an average of $42 \%$ / year in the period. 2010-2018, the increase in Vietnam's external debt during this period reached $16.7 \%$ per year. In 2017 alone, foreign debt reached $48.9 \%$ of GDP, close to the threshold of serious debt and close to the threshold of $50 \%$ allowed by the National Assembly. By 2018 this debt level has fallen to $46 \%$.

For public debt: Although the public debt ratio is still within the permitted limits $(50 \%$ $60 \%$ of GDP), this is a cause for concern because Vietnam is one of the countries with public debt to GDP ratio. Fastest increase (over 10\% / year) despite high economic growth. When compared with other countries in Southeast Asia, the public debt / GDP ratio of Vietnam is quite high, ranking second after Singapore. However, to assess the safety level of a country's public debt, it depends not only on public debt / GDP but also on other macroeconomic factors such as GDP growth rate, inflation, and interest rates. , the nation's current account deficit and foreign exchange reserves... 
Table 1. Unemployment rate of Vietnam and other countries in the region in 2018 (\%) (Source: ILO).

\begin{tabular}{|c|c|c|c|}
\hline \multirow{2}{*}{ Country } & \multicolumn{3}{|c|}{ Unemployment rate (\%) } \\
\cline { 2 - 4 } & Average & Male & Female \\
\hline Viet Nam & 2 & 2.1 & 2 \\
\hline Brunei Darussalam & 8.7 & 7.7 & 10.1 \\
\hline Indonesia & 4.4 & 4.5 & 4.2 \\
\hline Lao PDR & 9.4 & 10.8 & 7.8 \\
\hline Malaysia & 3.3 & 3.1 & 3.6 \\
\hline Myanmar & 0.9 & 0.7 & 1 \\
\hline Philippines & 2.3 & 2.1 & 2.7 \\
\hline Singapore & 4.1 & 3.8 & 4.5 \\
\hline Thailand & 0.7 & 0.7 & 0.7 \\
\hline Cambodia & 0.7 & 0.6 & 0.9 \\
\hline ASEAN & 3.7 & 3.7 & 3.7 \\
\hline Universe & 5.7 & 5.5 & 6.2 \\
\hline
\end{tabular}

(2) Budget deficit

According to [7] the budget deficit is $15 \%$ of the total budget revenue. If this level is exceeded, the budget revenue is unsustainable and the country may fall into financial exhaustion, which makes the economy more likely to lead to instability. The budget deficit (according to Vietnam's calculation) has increased from an average of $4.9 \%$ of GDP in the 2000-2005 period to $5.53 \%$ of the GDP in the 2006-2010 period.

In the period of $2011-2013$, although it decreased compared to the previous period, it was still high (average $4.85 \%$ of GDP), in the period of 2014-2018, the average deficit was $4.82 \%$ of GDP. Considering the ratio of budget deficit to total state budget revenues, most of these indicator years of Vietnam are greater than $15 \%$.

Table 2. Some key indicators of Vietnam's foreign debt 2006-2018 (Source: 2018 Statistical Yearbook, Ministry of Finance).

\begin{tabular}{|c|c|c|c|c|c|}
\hline Year & $\begin{array}{c}\text { Government } \\
\text { debt to GDP } \\
\mathbf{( \% )}\end{array}$ & $\begin{array}{c}\text { Foreign } \\
\text { debt / } \\
\text { GDP (\%) }\end{array}$ & $\begin{array}{c}\text { Government debt } \\
\text { repayment obligations } \\
\text { compared to state } \\
\text { budget revenues (\%) }\end{array}$ & $\begin{array}{c}\text { Obligation to } \\
\text { repay foreign } \\
\text { debts / import- } \\
\text { export } \\
\text { turnover (\%) }\end{array}$ & $\begin{array}{c}\text { Public } \\
\text { debt / } \\
\text { GDP } \\
\text { (\%) }\end{array}$ \\
\hline 2006 & 26.7 & 31.4 & 15.1 & 3.7 & 42.9 \\
\hline 2007 & 28.2 & 32.5 & 16.4 & 3.6 & 45.6 \\
\hline 2008 & 25.1 & 29.8 & 16.8 & 3.5 & 43.9 \\
\hline 2009 & 29.3 & 39 & 17.2 & 5.1 & 49 \\
\hline 2010 & 44.6 & 42.2 & 17.6 & 3.4 & 56.3 \\
\hline 2011 & 43.2 & 41.5 & 15.6 & 3.5 & 54.9 \\
\hline 2012 & 39.4 & 37.4 & 14.6 & 3.5 & 50.8 \\
\hline 2013 & 42.6 & 37.3 & 12.6 & 4.3 & 54.5 \\
\hline 2014 & 46.4 & 38.3 & 13.8 & 4.1 & 58 \\
\hline 2015 & 49.2 & 42 & 14.9 & 4 & 61 \\
\hline 2016 & 52.7 & 44.8 & 20.5 & 3.9 & 63.7 \\
\hline 2017 & 51.7 & 48.9 & 18.3 & 6.1 & 61.4 \\
\hline 2018 & 50 & 46 & 17.1 & 7 & 58.4 \\
\hline
\end{tabular}

High budget deficits will lead to unsustainable state budget revenues and the country may become financially exhausted and destabilize the economy. This is a warning to budget security in particular and financial security in general.

(3) Inflation and monetary price stability

This is also an indicator to assess administrative capacity and effectiveness of the policy. According to [6] the inflation rate of a nation's economy $8 \%$ is considered harmful 
to the economy. In the period of 2000-2007, the inflation rate was maintained at a low and stable level, reaching an average of $6.93 \%$ / year. From 2008 onwards, inflation increased rapidly and reached the highest level in 2008 and 2011, respectively $23.1 \%$ and $18.7 \%$, exceeding safe inflation.

From 2012 onwards, inflation has been controlled and maintained at a low level so far, an average of $4.6 \%$ per year and 2018 inflation of $3.5 \%$ / year. Although inflation in recent years has been low, contributing to stabilizing prices and stabilizing financial markets, the risk of inflation remains in the near future as public debt increases rapidly and maximum allowed threshold.

\subsection{International balance of payments and external influence this indicator includes}

(1) Level of export orientation: this indicator is expressed in the ratio of trade to GDP.

From 2000 to 2011, Vietnam's trade balance was in deficit, import turnover was always much higher than export turnover. Prior to 2008, the trade deficit tended to increase from $2.8 \%$ of GDP in 2006 to $13.64 \%$ in 2008 . Accordingly, a high level of dependence on foreign trade would make the economy more vulnerable. Financial security is negatively affected by the solvency of the economy. Since 2008, the Government has implemented indepth economic reforms, the trade balance has reduced the deficit and surplus since 2012 and by 2018 reached a surplus of 6.3 billion USD. When the trade deficit situation is improved, the export turnover is higher than the import, showing that our country has reduced its dependence on foreign trade and reduced external influences on the economy. However, the trade surplus is still low (6,7\% of GDP in 2018) due to the fact that export has not improved much and the sign of surplus is not sustainable.

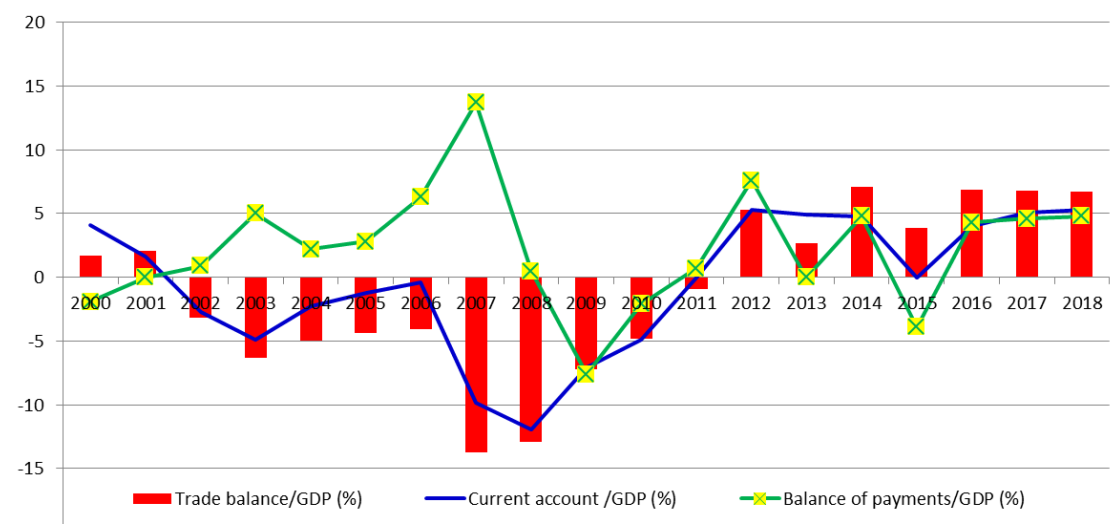

Fig. 3. Trade balance, current account and payment balance (Source: State Bank).

(2) The level of balance of international payment

In Vietnam's international payment balance, the current account has a major position, in which the trade balance is always in deficit. In addition, the balance of services and net income from outside during this period also had a deficit, resulting in a current account deficit in the period 2000-2010, particularly in 2009, Vietnam's current account deficit is USD 12.14 billion. By 2011, the State Bank of Vietnam applied measures to adjust the exchange rate, regulate the money supply and demand, increase the credit rate, so the current account deficit was reduced to 0.7 billion USD, equivalent to $0.5 \%$ of GDP. Since 2012, Vietnam's current account surplus was at a surplus of 9.3 billion USD, the capital balance also had a surplus, and the international payment balance of Vietnam has been in surplus and extended until now. 
(3) Capital account

After more than 30 years of reforming and reforming the economy since 1986, Vietnam's capital market has made remarkable achievements, actively contributing to the process of economic renovation and development. Capital inflows and outflows increase or decrease the amount of money in the economy, the more short-term capital flows, the more volatile and the market is more vulnerable to international financial shocks. This significantly affects the stability of the financial system in particular and the economy in general. In 2000, most enterprises borrowed capital from the banking system with a credit balance of $40 \%$ of GDP, The market capitalization of the stock market is $0.28 \%$ of GDP, by 2018 , outstanding loans have increased to $130 \%$ of GDP and the market capitalization of the stock market is over $70 \%$ of GDP. In addition, the total outstanding debt of the bond market in 2018 reached $37.45 \%$ of GDP, of which the outstanding amount of government bonds reached $27.4 \%$ of GDP.

(4) Liquidity and rationality of the scale of foreign exchange reserves

According to [6] a country with low or too thin foreign exchange reserves will cause a negative impact on its international solvency as well as its financial security. Conversely, if the foreign exchange reserves are too large, it will incur expenses for foreign exchange holding [7]. Since 2000, Vietnam's foreign exchange reserves have increased significantly and reached 10.2 billion USD in 2006, Vietnam's foreign exchange reserves have increased significantly in size since 2012. So far, this scale has not been large enough according to the world standards and has not been safe, stable, and able to intervene to reduce fluctuations in the foreign exchange market as well as the stability of the exchange rate, affect foreign payment debts.

\subsection{Financial development activities}

This index includes the following factors:

(1) Level of financial development: this indicator is measured by the credit growth indicator of the economy [8].

Before 2010, Vietnam had a high average credit growth rate, nearly $32 \%$ higher than the GDP growth rate of about $17 \%$ in the same period. The sharp increase in investment capital in Vietnam from 2005 to 2007 led to the credit growth of the economy reached a high level, about $51 \%$ in 2007. As a result, the inflation rate in $2007-2008$ increased highly, compared to 2007 , the consumer price increase in 2008 was $19.89 \%$. Through 2011 , the year was considered to be more volatile for the domestic financial market. However, thanks to the application of resolute and flexible measures of the State Bank, by the end of 2011, the credit growth of the whole system reached $14.2 \%$ and compared to 2010 , Credit growth has decreased significantly.

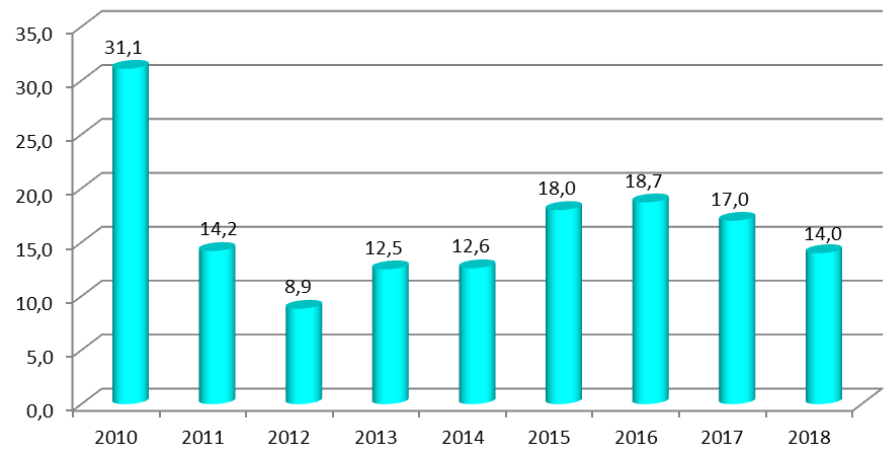

Fig. 4. Vietnam's credit growth period 2010-2018 (Source: State Bank). 
In general, in the period of 2010 - 2018, the average credit growth was $16.56 \%$ / year. In addition, credit growth in recent years has nearly tripled compared to nominal GDP growth. This also shows that rapid credit growth will increase the level of debt mobilization in the economy, amid concerns about increasing asset quality and bad debt.

(2) Financial asset price (Real interest rate) [9]

This index is measured through the real interest rate index of the economy. Prior to 2000 , the interest rate policy was mainly regulated by the State Bank and had many limitations in the management of interest rate policies. From 2001-2008, implementing the policy of removing interest rate ceilings by the state bank, apply base interest rate as a reference basis.

This created conditions for commercial banks and credit institutions to set their own interest rates, leading to an increase from $4.5 \%$ / year in 2000 to $7.6 \%$ / year in 2014 . In 2007, with this interest rate increase, it makes it difficult to manage and manage the interest rate of the State Bank, pushing up the interest rates in the market and in 2012, the State Bank applied the monetary tightening policy, interest rates tended to decrease in the market and has earned a base interest rate of 9\% per annum from 2012 to date. However, the current lending interest rate is still high, the difference between lending and deposit rates is still high, and bad debt is increasing. These are signs that the situation on the banking system has not been guaranteed yet [10].

(3) Exchange rate fluctuations [11]

In the 2000-2006 period, the exchange rate was governed in an ascending manner and published daily by the State Bank. The average interbank USD / VND exchange rate increased from VND 14,000 / USD in 2000 to VND 16,091 / USD at the end of 2006. Also during this period, the maximum amplitude was adjusted to increase only once from $0.1 \%$ to $0.25 \%$ in July 2002 . In the $2006-2010$ period, the interbank average USD / VND exchange rate remained on an upward trend and showed a devaluation of VND against foreign currencies.

By February 2011, the State Bank actively intervened in the foreign exchange market through VND devaluation. However, these are still administrative measures of the State Bank, not creating an environment for self-operating markets. Since 2012, the forex market has been stable, inflation is low and confidence in VND is higher [12].

In general, the management of exchange rate policy in this period was basically in accordance with market principles and certain positive changes. However, maintaining a stable exchange rate when foreign currency from abroad increases sharply increases money supply and contributes to macroeconomic instability, typically making Vietnam's inflation higher than other countries.

\section{Conclusion}

Through the assessment of the level of macroeconomic security of Vietnam from 2000 to present, it shows the safety level of Vietnam's financial system before the integration trend. Before 2007, the integration economy was still at a low level, less affected by changes in the world.

Through 2007, Vietnam participated in deeper integration into the world economy by joining the World Trade Organization (WTO), which means opening the financial market. Along with the instability of the world economy, it has a significant impact on Vietnam,

Seriously affecting national financial security reflected by the instability of macroeconomic factors as analyzed above. Since 2012, the Government has restructured the financial system and many other measures, the macroeconomic indicators have gradually stabilized and prospered, but are still unsustainable and still contain potential risks. Greatly affect the assurance of national financial security, the macroeconomic 
indicators have gradually stabilized and prospered, but are still unsustainable and still contain potential risks. Greatly affect the assurance of national financial security

\section{References}

1. D. Ushakov et al E3S Web of Conferences, 164, 09004 (2020)

2. T.H. Ai, T.V. Hung The EUrASEANs, 6(7), 39-50 (2017)

3. T.H. Ai, T. Tuan, V. Bui The EUrASEANs, 1(20), 07-22 (2020)

4. L.P. Koval Financial Space, 3(11), 101-103 (2013)

5. G. Pochenchuk Scientiae Oeconomina, 2(2), 29-37 (2014)

6. M. Privarova, A. Privara International J. Of Environmental \& Science Education, 11 (18), 12909-12917 (2016)

7. D.T. Tho, T.T. Thanh J. of Economics and Development, 216 (II) (2015)

8. A. Privara, M. Privarova Sustainability, 11, 5586 (2019)

9. A. Privara Geographical Journal, 71(2), 161-180 (2019)

10. S. Grib J. of Siberian Federal University. Humanities \& Social Sciences, 11, 23162324 (2015)

11. X. Cheng, Research of China's Financial Safety Indicator (2nd International Conference on Industrial Economics System and Industrial Security Engineering) (2015)

12. V. A. T. Duong, L. Pushkareva, E3S Web of Conferences 164, 11011 (2020) doi:10.1051/e3sconf/202016411011 